\title{
A Magyar Királyi Honvéd Légierő Bf 109-es vadászrepülőgépének nyomában m.rosz
}

\section{ESEMÉNYEK A KÉRDÉSES IDŐPONTBAN}

1944. december 11-én, mint minden háborúban álló ország, Magyarország légtere is megtelt repülőgépekkel. $E$ napok harcai három súlyponti részre oszthatók.

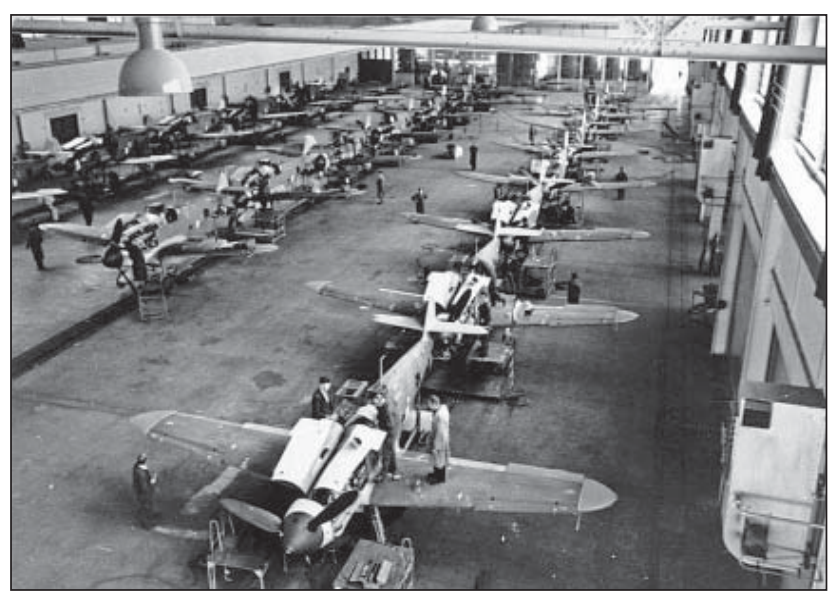

15. ábra. Az Me 109-es gyártása. Hazánkban 723 db-ot gyártottak ebböl a típusból a II. világháború alatt

$A z$ amerikai bombázók légi eseményei nem kötődnek az általunk kutatott eseményhez. Aznap, 11-én az amerikai kötelékek a Bécs környéki olajfinomítókat támadták. Kisebb kötelékek magyar légtérbe keveredtek. A Gönyűnél horgonyzó SZEGED őrnaszád tüzérsége is lelőtt egy Liberátort, amely a csicsói erdőre zuhant le. ${ }^{12}$ A Magyarország légterébe érkező 451. bombázócsoportból (az előzővel együtt) három, a 450. bombázócsoportból egy B-24-es Liberátor zuhant alá, még a frontvonal átrepülése előtt a mélybe.

\section{1. táblázat}

\begin{tabular}{|c|c|c|c|c|c|c|}
\hline Típus & BG & Sq & SerNo & MACR & Hely & Pilóta \\
\hline B24G & 450 & 721 & $42-78454$ & 10493 & Zalagalsa & 2Lt Berry \\
\hline B24J & 451 & 725 & $44-10629$ & 10367 & Csicsó, Duna-part & 1Lt Campbell \\
\hline B24J & 451 & 726 & $42-51585$ & 10391 & Sümeg É-Ny & 2Lt Porter \\
\hline B24H & 451 & 727 & $42-50630$ & 10392 & Komárom környéke & 1Lt Harris \\
\hline B24G & 456 & 746 & $42-51548$ & 10363 & Zsigárd (Szlovákia) & F/O Kennedy \\
\hline B17G & 483 & 817 & $44-8111$ & 10129 & Berzence, Böhönye & 1Lt Jarrett \\
\hline B17G & 301 & 32 & $44-6529$ & & Debrecen, Repülőtér & Lt Morris \\
\hline
\end{tabular}

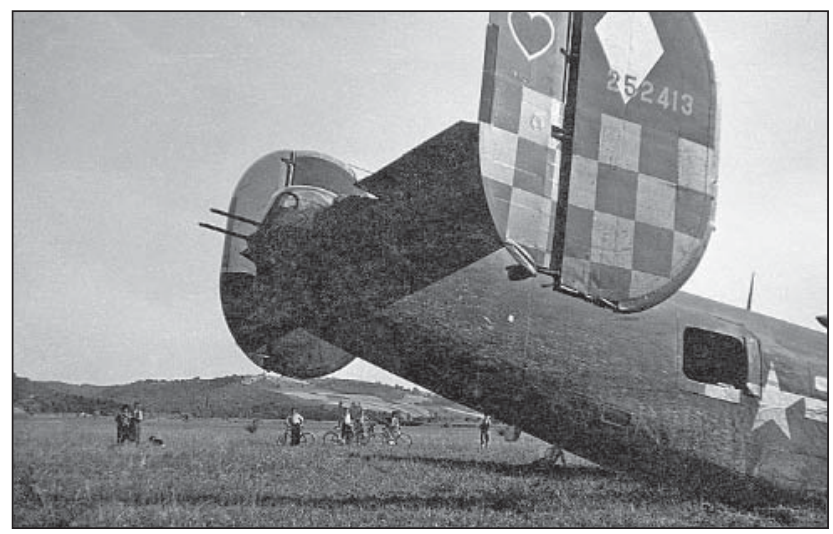

16. ábra. Lelövését követően magyar területen kényszerleszállt B-24-es Liberator bombázó (Fortepan 15561)

Az átrepülő repülőgépek közül a 456. és a 483. bombázócsoportból további egy-egy repülőgép elérte a szovjet megszállás alatt levő területet, de azok is lezuhantak. Egy repülőgép pedig a 301 . bombázócsoportból a szovjet kézen levő debreceni repülőtéren szállt le. E repülőgépek sem az amerikai, sem a német jelentések szerint nem találkoztak ellenséges vadászrepülőgépekkel. Az összesített jelentés pontosítja, illetve kiegészíti a történteket. (1. táblázat)

A front akkori állása a Balaton északi csücske, Székesfehérvár-kelet - Martonvásár - Ócsa - Gödöllő - Vác-kelet és a Börzsöny hegységen keresztül Balassagyarmat vonalában húzódott. A Németország felett alighanem megsérült bombázók igyekeztek elérni a szovjet vonalakat. A hét repülőgépből csak egy érte el célját, a többi odaveszett. A frontvonal déli végén, a Balaton és Dunántúl környékén, a szovjet légierő több bevetést hajtott végre.

A Dunántúlon felélénkülő katonai mozgás a déli órákban a 17. szovjet légi hadsereg vadász- és csatarepülőgép kötelékeinek tevékenységét váltotta ki. A szovjet csatarepülőgép támadások elsősorban a SzékesfehérvárVeszprém-Jánosháza között húzódó, 8. számú főközlekedési út és vasút hadiforgalmát érték. Délelőtt 11 óra előtt a-mozgósított újoncokkal zsúfolt - devecseri vasútállomást támadó csatarepülőgépek ellen azonnal harc-

Országos Vízügyi Főigazgatóság, Főtanácsos. A Magyar Roncskutató Egyesület és a Magyar Veterán Repülők Szövetsége tiszteletbeli elnöke. Baja Főiskola szakmérnök, vízügyi gépészeti oktató. 


\section{2. táblázat}

\begin{tabular}{|c|c|c|c|c|}
\hline \multirow{2}{*}{ Típus } & \multicolumn{2}{|c|}{ Csatarepülö } & \multirow{2}{*}{ Hely } & \multirow{2}{*}{ Esemény } \\
\hline & hadosztály & ezred & & \\
\hline II-2m3 & & 615. & Ajka Kislőd légterében: & $\begin{array}{l}\text { Légi harc vagy légvédelmi találat. } \\
\text { Harci bevetésből nem tért vissza. }\end{array}$ \\
\hline II-2m3 & 136. & 715. & Csősz légterében: & Légi harc vagy légvédelmi találat. \\
\hline II-2m3 & 136. & 989. & Szabadbattyán-Kelet légterében & Légi harc. Harci bevetésből nem tért vissza. \\
\hline II-2m3 & & 615. & Dunántúl légterében & Harci bevetésből nem tért vissza. \\
\hline IL-2m3 & & 187. & Ismeretlen légtérben & Harci bevetésből nem tért vissza. \\
\hline
\end{tabular}

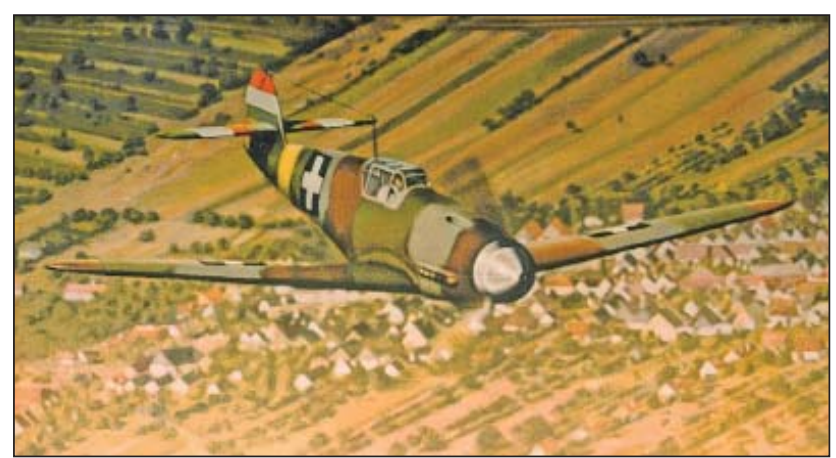

17. ábra. Magyar Bf 109F-2-es minta vadászrepülőgép egy színezett fényképfelvételen, 1943-ban

ba vetették Kenyeriből a 101/II. magyar vadászrepülő osztály két repülőgépét. Szecsey Gábor repülő hadnagy Messerschmitt Bf 109 típusú vadászrepülőgépével az egyik szovjet köteléket megtámadta és az egyik II-2m3 típusú csatarepülőgépet Ajka-Kislőd térségében lelőtte. A szovjet források pontosítottak és további $4 \mathrm{db}$ szovjet csatarepülőgép lezuhanásáról is tájékoztattak. (2. táblázat)

A vasútállomások és repülőterek támadása mellett egy magányos felderítő repülőgép is tevékenykedett a Dunántúlon. Talán magára maradottsága okozhatta vesztét a szerencsétlen sorsú repülőgépnek.

December 11-én 14 óra 53 perckor a 17. légi hadsereg 39. távolsági felderítő repülőezred egy Pe-2PF típusú felderítő bombázóját Helmuth Lipfert szds. (6./JG 51) Balatonkenese felett 4500 méter magasságban meglepte és lelőtte. A levegőben szétrobbant repülőgép Balatonkenesénél a vízbe zuhant. $A$ maradék roncsokat a repüléstörténet-kutatók 1994-ben kiemelték a Balatonból. ${ }^{13}$

A csatarepülőgépek védelmére a szovjet vadászrepülögépeket is a légtérbe küldték. Ezek közül - az eddigi tudomásunk szerint - a 288. vadászrepülő-hadosztály, a 866. vadászrepülő-ezred állományába tartozó kettő Jak-9 vagy Jak-3 típusú repülőgépet Pákozd - Sukoró légterében a vadászvédelem lelőtt. A szovjet hadijelentések szerint „harci bevetésből nem tértek vissza”.

18. ábra. Bf 109G-14-es vadászrepülögép magyar alkalmazásban

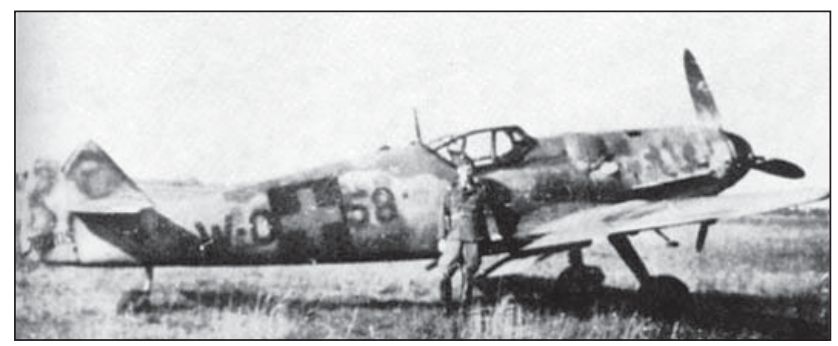

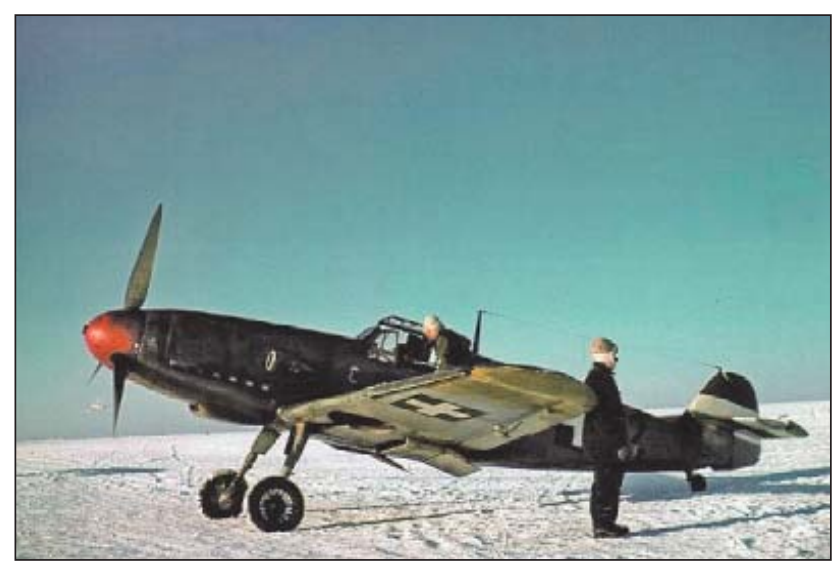

19. ábra. Bf 109G-2-es a Magyar Királyi Légierő színeiben, 1943 januárjában

Valószínűleg e helyszíntől kissé eltávolodott a küzdelem. Heinz Ewald hadnagy a 6./JG 52. vadászszázad pilótája, a szovjet 150 . vadászrepülő-hadosztály 149 . vadászrepülöezredéhez tartozó Jak-1 vagy Jak-9 típusú repülőgépével ütközött meg, amelyet, a német jelentések szerint Ercsi Martonvásár légterében, 4500 méter magasságban lelőtt. Az előző két repülőgépről feltételezhető, hogy azokat szintén a 6./JG 52. vadászszázadhoz tartozó Steins fötörzsőrmester, és Welz őrmester lőhette le, akik 1200 méter magasságban találkoztak a szovjet vadászrepülőgépekkel.

A magyar jelentések egyike szerint, aznap Budapest légterében jelentősebb eseményekre nem került sor. „A délutáni órákban 13 óra 30 perc és 14 óra 55 perc között a Veszprém-Jutas repülőtérről felszálló 101/l. magyar vadászrepülö-osztály kötelékerejű szabadvadászatot végzett a főváros légterében - minden eredmény nélkül."14

Ugyanakkor Budapest észak, északkeleti térségében a földön súlyos gyalogsági harcokra került sor. A 30. szovjet lövészhadtest, 36. szovjet gárda lövészhadosztálya elfoglalta Gödöllőt. Az Ipoly arcvonalon Drégelypalánk körzetében a 6 . szovjet gárda harckocsihadsereg, 9. gárda gépesített hadtestének csapatai erőltették a támadást Ipolyság általános irányba, hogy áttörve az Ipolyon, Léva felé mérjék főcsapásukat. Aznap este a 10. magyar felderítőosztály katonáit a Gödöllő - Mogyoród vonalra vonták vissza. A 10. magyar kaposvári gyaloghadosztály hadműveleti naplójában feljegyezték, hogy „a nap folyamán a hadosztály légterében erős szovjet légi tevékenység zajlott. A hadosztály légvédelmi tüzérsége egy szovjet repülőgépet lelőtt."

A szovjet hadijelentések szerint Budapesttől északkeletre két repülőgép légi harcban, egy pedig ismeretlen ok miatt veszett el. (3. táblázat)

A német légi csatarepülő és vadászrepülő győzelmi névsor csupán egy repülőgép lelövéssel több, mint amit a szovjet jelentésekből ki lehet olvasni. Minden bizonnyal, 


\section{3. táblázat}

\begin{tabular}{|l|l|l|l|}
\hline Jak-9 & 151. gárda vadászrepülő ezred & Fót - Mogyoród légterében & Légi harc. Harci bevetésből nem tért vissza. \\
\hline II-2m3 & 132. gárda csatarepülő ezred & Vácrátót-Észak légterében & Légi harc. Harci bevetésből nem tért vissza. \\
\hline II-2m3 & 90. csatarepülő ezred & Gödöllő légterében & Harci bevetésből nem tért vissza. \\
\hline
\end{tabular}

mint ahogy többször előfordult, egy repülőgépre ketten rátámadhattak, vagy egy repülőgép kétszer is rátámadt ugyanarra a repülőgépre és így adták be az igényüket.

\section{4. táblázat}

\begin{tabular}{|l|c|c|r|}
\hline Dudszus fötörzsőrmester & 8./SG 10 & II-2 & $2100 \mathrm{~m}$ \\
\hline Neumann örmester & 1./JG 53 & II-2 & $150 \mathrm{~m}$ \\
\hline $\begin{array}{l}\text { Jürgen Harder Stab } \\
\text { őrnagy }\end{array}$ & I./JG 53 & II-2 & $800 \mathrm{~m}$ \\
\hline Friedrich Haas hadnagy & $5 . / J G 52$ & Jak-9 & $800 \mathrm{~m}$ \\
\hline Friedrich Haas hadnagy & 5./JG 52 & Jak-9 & $1000 \mathrm{~m}$ \\
\hline
\end{tabular}

A német hadsereg részletesebb repülőgép-bevetésekről szóló jelentései szerint az Ipoly szakaszon vívott harcok- ban bevetették az I. német repülőhadtest több bombázó, csata- és vadászrepülő kötelékét, valamint a 102. magyar repülődandárhoz tartozó 102. vadászbombázó és 102. gyorsbombázó osztályait. A támadó repülőgépek a nap folyamán tíz szovjet páncélost semmisítettek meg, és ötöt megrongáltak.

A folyamatosan hátráló szárazföldi csapatok megfigyelése szerint „A déli órákban nyolc német bombázó repülőgép jelent meg Bernecebaráti légterében, s bombázták az előrevetett szovjet páncélos éket. A szovjet csapatlégvédelmi tüzérség zárótüzében az egyik német bombázó repülőgép találatot kapott és lezuhant. A többi repülőgép bombái is többségében az Ipoly árterében robbantak".

A jelentés alapján felmerül a kérdés: ebben az időben vajon mi történhetett Budapest nyugati légterében?

A kutatások során az alábbiakat sikerült feltárni: 1944. december 31-én a 102. magyar repülődandár egységei

20. ábra. Egy 1944-es Messerschmitt naptárban közölt színes fénykép egy magyar álcázó színekre festett, korábban a magyarországi gyártás beindításához küldött, német Bf 109F-1-es mintagépet ábrázol' ${ }^{15}$ (A felvétel 1943-ban készült) 
összefoglaló jelentést adtak ki a decemberi tevékenységükről. A 101. vadászrepülő-ezred szóvá tette, hogy „A német pilóták kétes esetekben a magyarokat is megtámadták. A német Focke-Wulf Fw 190 típusú repülőgépek több ízben a magyar repülőgépekre is tüzeltek tévedésből."

Vajon ennek a december 31-én kiadott összefoglaló jelentésnek lehet valóságtartalma?

\section{A MessersSChMitTeK elLeNSÉGGé váltaK}

A Németországgal szövetségben levő román légierő részére 1943 tavaszán megérkezett a beígért korszerű német repülőanyag második része is. A fél évvel korábban leszállított Bf 109 G-4-es korai változatai mellé ezúttal újabb, immáron Bf 109 G-6 típusú repülőgépek érkeztek.

Az átvett repülőgépek 1944. év közepétől már kerülték a túlerőben levő amerikai és szovjet légierővel történő öngyilkossággal egyenértékű nyílt ütközetet. Augusztus 19-én a román légierőt széttelepíttették, így várva be a román király rádióüzenetét, amelyben bejelentette a kapcsolatok megszakítását a tengelyhatalmakkal. Ezzel a román légierő számára a keleti hadjárat véget ért.

1944. szeptember 1-jén a szovjet utasításnak eleget téve, a FARR ${ }^{16}$ főhadiszállása az összes román repülőgép felszállását megtiltotta. Az új politikai rendszer megkövetelte, hogy a repülőgépek jelzéseit is megváltoztassák. Az 1941 májusa előtt érvényben levő kör alakú trikolórt vezették be újra. Ez a jelzés 1944. szeptember 3-án lett hivatalos, de a háború előtti néggyel szemben, ezúttal hat helyen festették fel ugyanoda, mint ahol a korábbi Mihály-kereszt volt felfestve. A tengelyhatalmak sárga azonosító jelét, amelyet az alsó szárny végére és a törzs hátsó részére

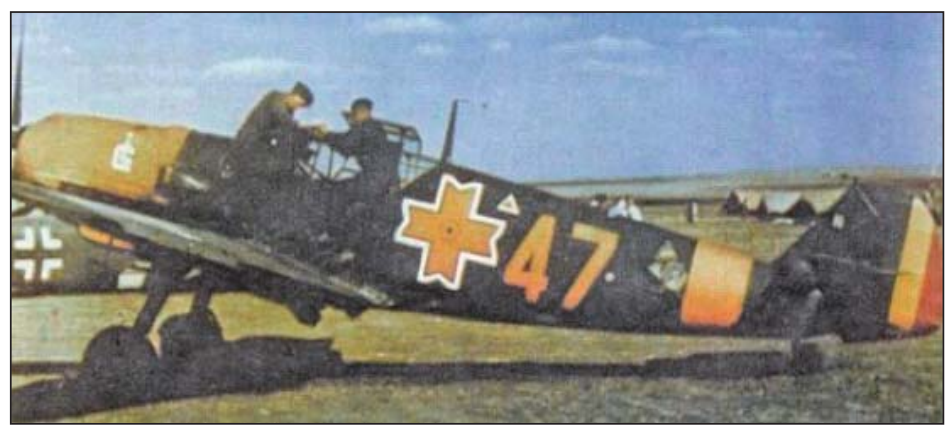

21. ábra. A román átállást megelőzően alkalmazott hadijel Mihály-kereszt - egy Bf 109E-4es gépen

22. ábra. Az átállás utáni román jelzéseket viseló Messerschmitt Bf 109G-6 típusú repülögép

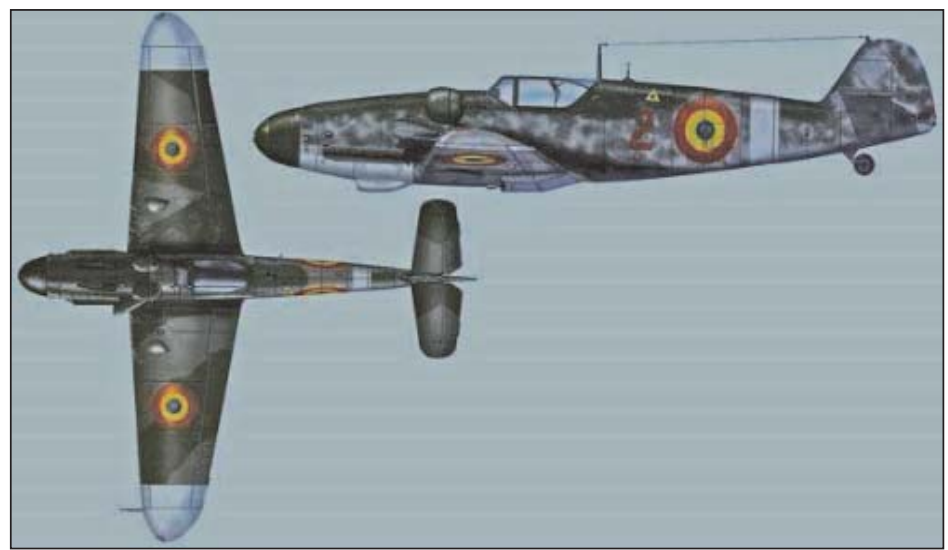

gyűrü alakban vittek fel, a szovjet 5. légi hadsereg jelzéséhez hasonlóan, ekkortól fehér színnel festették fel. A jelzések átfestése a gyártási számokat, és egységek jeleit nem érintette. Fehérre kellett festeni továbbá a felső szárnyvégeket és a motorház alsó részét. Ez utóbbi festés nem minden román gépen lett végrehajtva.

A román kiugrás után az eddigi szövetséges ellenséggé vált. Szeptember 14-én a német Fw 190 típusú repülőgépek már három román Ju 87-es Stukát lőttek le. A Messerschmitt 109 típusú repülőgépek első összecsapására nem kellet sokat várni. Szeptember 18-án két német repülőgép támadott öt román Messerschmittre. A németek saját veszteség nélkül, két román repülőgépet lőttek le.

A német jelentések szerint az esemény 19-én történt. Heinrich Tammen főtörzsőrmester és egy másik altiszt a 6/JG 52. vadászrepülő századtól 1500 és 5000 méter magasságban támadtak a román repülőkre.

A pálfordulás idején kb. 500 harci repülőgéppel rendelkezett a román légierő, de szeptember végére ez a nagyságrend már lecsökkent 200 darabra. Ebből 27 darab Bf 109 G típusú repülőgép lehetett. A németek, a román átállást hihetetlennek fogták fel. Októberben Magyarország tétova kísérlete következett. A román légierő német gyártású repülőgépei itt harcoltak Magyarország légterében. A román átállást követően, december 11-ig a német légierő már hét román légierő által használt Bf 109-es repülőgép felett aratott légi győzelmet. Elég egy ködös idő, egy hirtelen felindulás, egy „inkább én lőjek előbb, minthogy engem lőjenek le" látomás és így szembe kerülhettek azok is, akiknek egy oldalon kellett volna állniuk. A német légierő 5./JG 51-es pilótái 1944. december 11-ére három Messerschmitt Bf 109 típusú repülőgép felett aratott légi győzelmi igényt jelentettek be.

\section{5. táblázat}

\begin{tabular}{|l|c|c|c|}
\hline Elias Kühlein hadnagy & 5./JG 51 & Bf 109 & 3000 m \\
\hline Heinisch őrmester & 5./JG 51 & Bf 109 & $3000 \mathrm{~m}$ \\
\hline Klein őrmester & 5./JG 51 & Bf 109 & $1800 \mathrm{~m}$ \\
\hline
\end{tabular}

A román repüléstörténelmi írások pedig erre a napra még román bevetést sem említenek. Azóta sem tudjuk biztosan, hogy mi történt a felhők felett. Talán hárman is rátámadtak egymás után ugyanarra a repülőgépre. Akkor gyötrelmes volt az élet, már a jelentésekről nem lehetett meggyőződni. Napjainkra a mindent kizáró, értékelhető bizonyítékok is szétporladtak.

\section{JegYzetEK}

12 Ez utóbbi repülőgép a 451 stBomb Group „Buzz Baby” nevű repülőgép volt, amely 23000 láb magasságban, Bécs légterében a légvédelem eltalált. Chuck Campbell pilóta azonnal meghalt. A repülőgép mégis elvergődött a Duna környékéig. Aviator International 1996. április száma. 24. oldal. A sérült repülőgépek útvonalát tekintve valószínűleg az őrnaszád 1Lt Harris. 42-50630 gyári számú repülőgépére nyitott tüzet, amely felette repült el, és Komárom környékén zuhant le;

13 Haditechnika 1996. évi 4. szám;

14 Veres D. Csaba: Magyarország hadikrónikája;

15 A repülögépet itthon egy elképzelt (tervbe vett) magyar szabványnak megfelelő, a németnél látványosabb és markánsabb színekkel festettek át és magyar felségjelzéssel láttak el. A korabeli nyomdatechnika hiányosságai miatt a színárnyalatok csak hozzávetőlegesek;

16 (FARR) Forțele Aeriene Regale Române (Román királyi légierő). 